1815

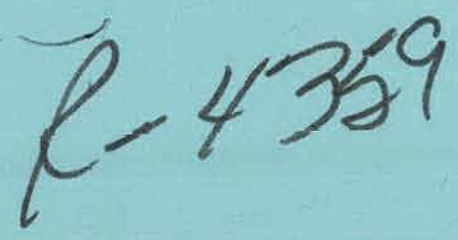

UC-96

\title{
Methyl Aryl Ethers from Coal Liquids as Gasoline Extenders and Octane Improvers
}

November, 1980

Prepared by:

Gary M. Singerman

Gulf Research and Development Company

Pittsburgh, Pennsylvania 15230

Under Contract No. DE-AC01-79C50022

Prepared for:

The United States Department of Energy

Assistant Secretary for Conservation and Renewable Energy

Office of Transportation Programs

Washington, D.C. 20585 


\section{DISCLAIMER}

This report was prepared as an account of work sponsored by an agency of the United States Government. Neither the United States Government nor any agency Thereof, nor any of their employees, makes any warranty, express or implied, or assumes any legal liability or responsibility for the accuracy, completeness, or usefulness of any information, apparatus, product, or process disclosed, or represents that its use would not infringe privately owned rights. Reference herein to any specific commercial product, process, or service by trade name, trademark, manufacturer, or otherwise does not necessarily constitute or imply its endorsement, recommendation, or favoring by the United States Government or any agency thereof. The views and opinions of authors expressed herein do not necessarily state or reflect those of the United States Government or any agency thereof. 


\section{DISCLAIMER}

Portions of this document may be illegible in electronic image products. Images are produced from the best available original document. 


\section{NOTICE}

This report was prepared as an account of work sponsored by the United States Government. Neither the United States nor the United States Department of Energy, nor sny of their employees, makes any warranty, express or implied, or assumes any legal liability or responsibility for the accuracy, completeness, or usefulness of any information, apparatus. product, or process disclosed, or represents that its use would not infringe privately owned rights. Reference herein to any specific commercial product, process, or service by trade name, mark, manufacturer, or otherwise, does not necessarily constitute or imply its endorsement, recommendation, or favoring by the United States Government or any agency thereof. The views and opinions of authors expressed herein do not necessarily state or reflect those of the United States Government or any agency thereof.

Available from:

National Technical Information Service (NTIS) U.S. Department of Commerce 5285. Port Royal Road Springfield, Virginia 22161

Price: $\quad$ Printed copy: $\quad \$ 6.00$

Microfiche: $\quad \$ 4.00$ 


\section{Methyl Aryl Ethers from Coal iquids as Gasoline Extenders and Octane Improvers}

November, 1980

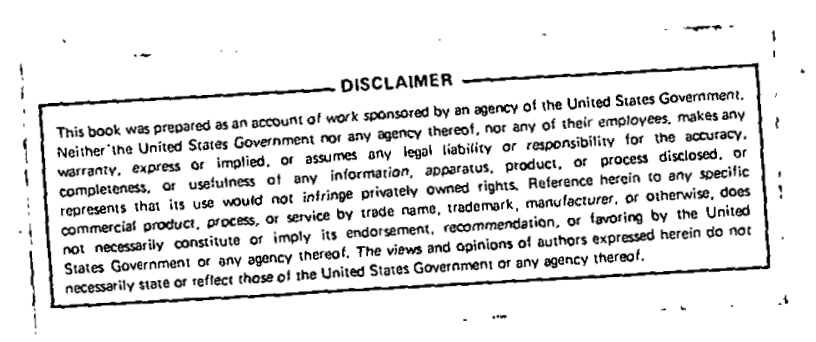

Prepared for:

The United States Department of Energy

Assistant Secretary for Conservation and Renewable Energy

Office of Transportation Programs

Under Contract No. DE-AC01-79CS50022 
FORWARD

In order to determine if an alternative fuel could replace or extend the supply of petroleum, it is essential to achieve an extremely high degree of reliability. This requires solutions to many real and potential problems. The work reported here deals with the evaluation of a mixture of methyl aryl ether derived from coal liquids as a gasoline extender and octane improver.

The Department of Energy is pleased to have this highly professional addition to alternative fuels application knowledge as reported by Dr. Gary M. Singerman.

Ralph D. Fleming

Vehicle Systems and Fuels Integration Branch Transportation Programs Office of Assistant Secretary Conservation and Renewable Energy 


\section{TABLE OF CONTENTS}

PAGE

ACKNOWLEDGEMENT..............................ifi

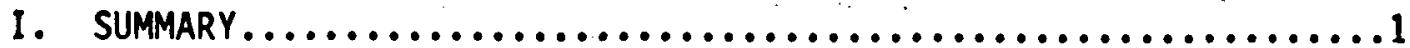

II. INTRODUCTION.....................................

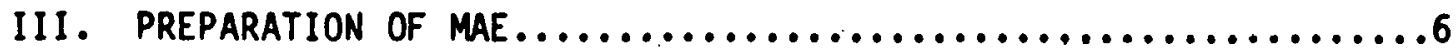

IV. ANALYTICAL INSPECTION OF MAE $\ldots \ldots \ldots \ldots \ldots \ldots \ldots \ldots \ldots \ldots \ldots$

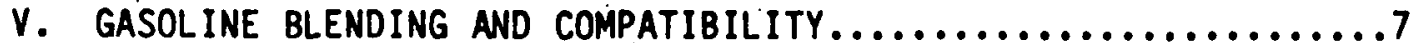

VI. PLASTICS COMPATIBILITY............................

VII. MICROBISTATIC PROPERTIES ...........................

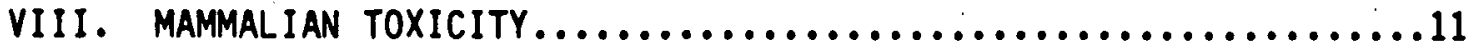

IX. oCTANE QUALITY.................................

X. CARBURETOR CleANLINESS $\ldots \ldots \ldots \ldots \ldots \ldots \ldots \ldots \ldots \ldots \ldots \ldots \ldots \ldots$

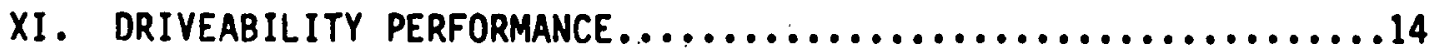

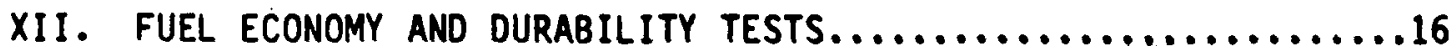

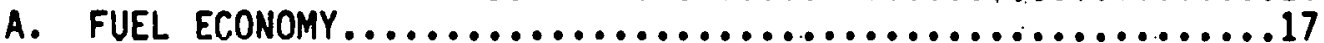

B. SPARK PLUG FOULING. ......................... 18

C. OIL CONSUMPTION .............................. 18

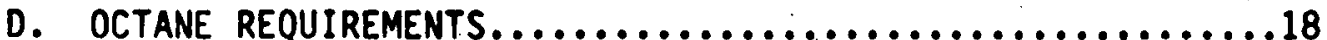

E. ENGINE WEAR .................................18

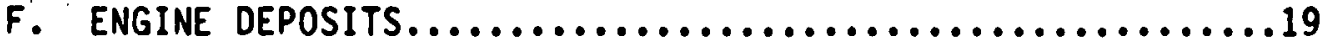

G. EXHAUST EMISSIONS.............................19

XIII. CONCLUSIONS ..................................21

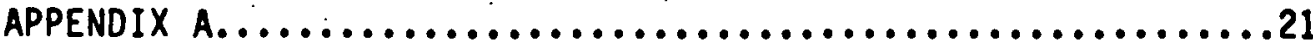

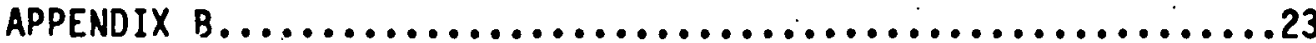

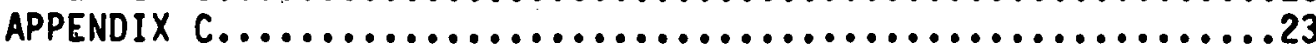

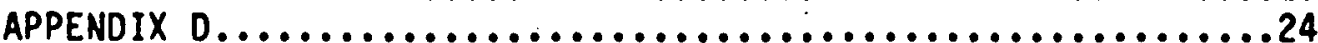

APPENDIX E................................... 25

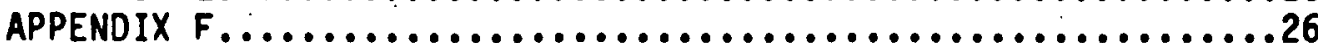

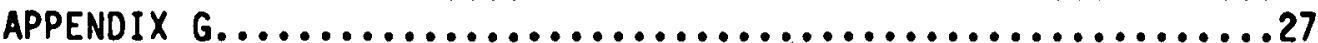

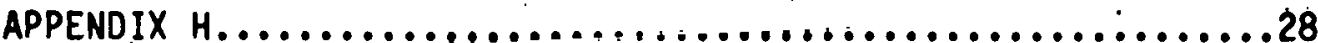

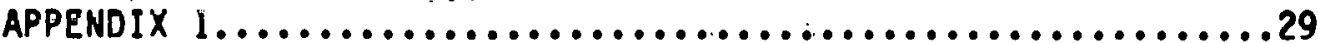

REFERENCES ........................................ 30 
THIS PAGE

\section{WAS INTENTIONALLY LEFT BLANK}




\section{ACKNOWLEDGEMENT}

This work was conducted by Gulf Research Development Company for the U.S. Department of Energy, Office of Transportation Programs, under Contract Number DE-AC01-79CS50022. The author thanks Dr. Ralph Fleming of the U.S. Department of Energy for his interest, advice, and encouragement throughout the course of this study. 
THIS PAGE

WAS INTENTIONALLY

LEFT BLANK 


\section{THIS PAGE}

WAS INTENTIONALLY

LEFT BLANK 
and Western coals, the solvent refined coal process produces $1 \%$ phenol and $4 \%$ mixed cresols based on coal input (2).

A Battelle study shows that the $H$-coal liquefaction process gives 7.93 wt. \% of phenols in the $\mathrm{C}_{4}-204^{\circ} \mathrm{C}\left(400^{\circ} \mathrm{F}\right)$ fraction. A coal hydrogenation plant with a daily production capacity of $30,000 \mathrm{bbl}$. liquid will produce 1,380 bbl/day of a mixture of phenol, cresols, and xylenols (2). Another study of the $H$-coal process showed that when the process is producing fuel 011, the product boiling below $203^{\circ} \mathrm{C}\left(397^{\circ} \mathrm{F}\right)$ contains $22.3 \mathrm{wt}$. \& $\mathrm{C}_{6}-\mathrm{C}_{9}$ phenols (7.94 wt. \& total distillate). When producing Syncrude, the product boiling below $197^{\circ} \mathrm{C}\left(387^{\circ} \mathrm{F}\right)$ contains 14.5 wt. \& $C_{6}-C_{9}$ phenols $(5.01$ wt. \% total distillate) (3).

In experimental coal liquefaction studies on a variety of Eastern bituminous coals performed at Gulf Research \& Development Company using a one ton per day SRC II process demonstration unit, the phenol's in raw liquid product have been studied. The phenols in a raw liquid product cut that boils In a range of about $55^{\circ} \mathrm{C}\left(150^{\circ} \mathrm{F}\right)$ to $260^{\circ} \mathrm{C}\left(500^{\circ} \mathrm{F}\right)$ were determined by gas chromatography. This cut represents about $18-20 \%$ of the coal fed to the demonstration unit and about $50 \%$ of the liquid product. For a series of eight runs, phenolic content varied in this cut from $10.2 \%$ to $51.7 \%$. The phenols in a $55^{\circ} \mathrm{C}\left(131^{\circ} \mathrm{F}\right)$ to $249^{\circ} \mathrm{C}\left(480^{\circ} \mathrm{F}\right)$ cut from a typical run on the SRC II process demonstration unit are shown in Table 1. The amount of phenols in this cut was 24.7 wt. \%. 
Table 1

Phenolic Compounds Identified by Gas Chromatography in a $55^{\circ}-249^{\circ} \mathrm{C}$ Raw SRC II Coal Liquid Fraction

\begin{tabular}{lc} 
Phenolic Compound & Weight $\%$ \\
\hline Phenol & 5.58 \\
Ortho-Cresol & 2.31 \\
Meta-Cresol & 3.65 \\
Para-Cresol & 2.30 \\
2,4-Dimethylphenol & 0.77 \\
2,5-Dimethylphenol & 0.38 \\
2,6-Dimethylphenol & 0.20 \\
3,4-Dimethylphenol & 0.12 \\
3,5-Dimethylphenol & 0.82 \\
Ortho-Ethylphenol & 0.32 \\
Para-Ethylphenol & 0.91 \\
Propylphenol & 1.86 \\
Unidentified Phenols & 5.48 \\
&
\end{tabular}

The raw coal liquid used in the present work came from a composite of fifty-one coal liquefaction runs on Eastern bituminous coals fed to Gulf Research \& Development Company's one ton per day SRC II process :demonstration unit. From this liquid composite, we used a cut having a bolling range of $55^{\circ} \mathrm{C}\left(131^{\circ} \mathrm{F}\right)$ to $260^{\circ} \mathrm{C}\left(500^{\circ} \mathrm{F}\right)$. This cut contained 28.8 wt. \% of phenolics.

Almost certainly, if direct coal liquefaction becomes commercially significant, far more phenolics will be produced than can be absorbed by the combined demand of all chemical industries utilizing phenolics. Other, non-chemical industry uses must be found for coal phenolics. But they cannot be blended into gasoline to extend supplies and improve octane. This is unfortunate because phenols are excellent non-metallic octane improvers. Nevertheless, our studies have shown that phenols in gasoline are corrosive, may cause gum formation, and will cause some plastics and elastomers currently used in automotive gasoline systems to swell, harden, or crack (4). Just as important, phenols are poisonous by all routes of entry into the systemic circulation of mammals, absorbtion through the skin being the primary route of entry into the blood stream. Liquid phenol in contact with the skin may, cause local irritation or chemical burns. 
On the other hand, coal phenols could be left in the raw coal liquid and the mixture further processed by hydrotreatment as one step in producing high quality gasoline or distillate fuel. Hydrotreatment would reduce the phenolics to fuel-compatible materials. But hydrotreatment to reduce phenolics would require severe conditions and consume large amounts of hydrogen. From a processing standpoint, refining of raw coal liquids is hampered by the presence of phenolics because:

1. Excessive hydrogen consumption is requitred to reduce the phenols.

2. The combination of coal phenols (or some component therein) and chlorides is much more corrosive to processing equipment than efther one alone. Many coals have high chloride content (5).

3. Water produced when phenols are hydroreduced sinters refinery catalyst supports.

4. Presence of phenols hampers ease of nitrogen removal from coal liquids by hydrorefining. Kinetic studies by Suntech show that the rate constants for removal of nitrogen from phenol-free SRC II coal liquid by hydrorefining are increased by over a factor of six at 375 and $400^{\circ} \mathrm{C}$ compared to rate constants for whole, unextracted SRC II liquid. The significance of the increased hydrodenitrogenation rate constants is that the reactor can be smaller for a given capacity or more throughput can be obtained at milder conditions, both of which can result in lower operating costs (6).

Taking all factors into account, extraction of phenolics from raw coal liquid and conversion of the phenolics into MAE's may have significant merit in terms of gasoline octane improvement and possible improvements in the overall efficiency and economics of coal processing. 


\section{PREPARATION OF MAE}

A composite of raw coal liquid from fifty-one coal liquefaction runs on Eastern bituminous coals fed to Gulf Research \& Development Company's one ton per day SRC II process demonstration unit was used as the source of phenols. A cut (1019 gallons, 7574 lbs.) boiling in the range $55^{\circ} \mathrm{C}\left(131^{\circ} \mathrm{F}\right)$ to $260^{\circ} \mathrm{C}\left(500^{\circ} \mathrm{F}\right)$, was extracted with aqueous sodium hydroxide to give 2180 lbs. (28.8\%) of mixed phenols. The phenols were allowed to react with dimethyl sulfate to yield the MAE product. Details for these operations are given in Appendix A. Ideally, one would produce MAE by direct reaction of phenols with methyl alcohol. This has been done in small scale experiments, but process improvements and scale-up studies are needed.

\section{ANALYTICAL INSPECTION OF MAE}

Samples of the MAE product were analyzed for density, distillation curve, nuclear magnetic resonance spectrum, gas chromatography, infrared spectrum, and carbon, hydrogen, oxygen, and nitrogen content. The nuclear magnetic resonance and infrared spectra showed absorptions expected from a mixture of methyl ary 1 ethers corresponding to a mixture of phenols as shown in Table 1, but did not show any free, unreacted phenols. Gas chromatography also showed an absence of free phenol in the MAE product. Other inspection data are shown in Table 2. 
Table 2 - MAE Inspection

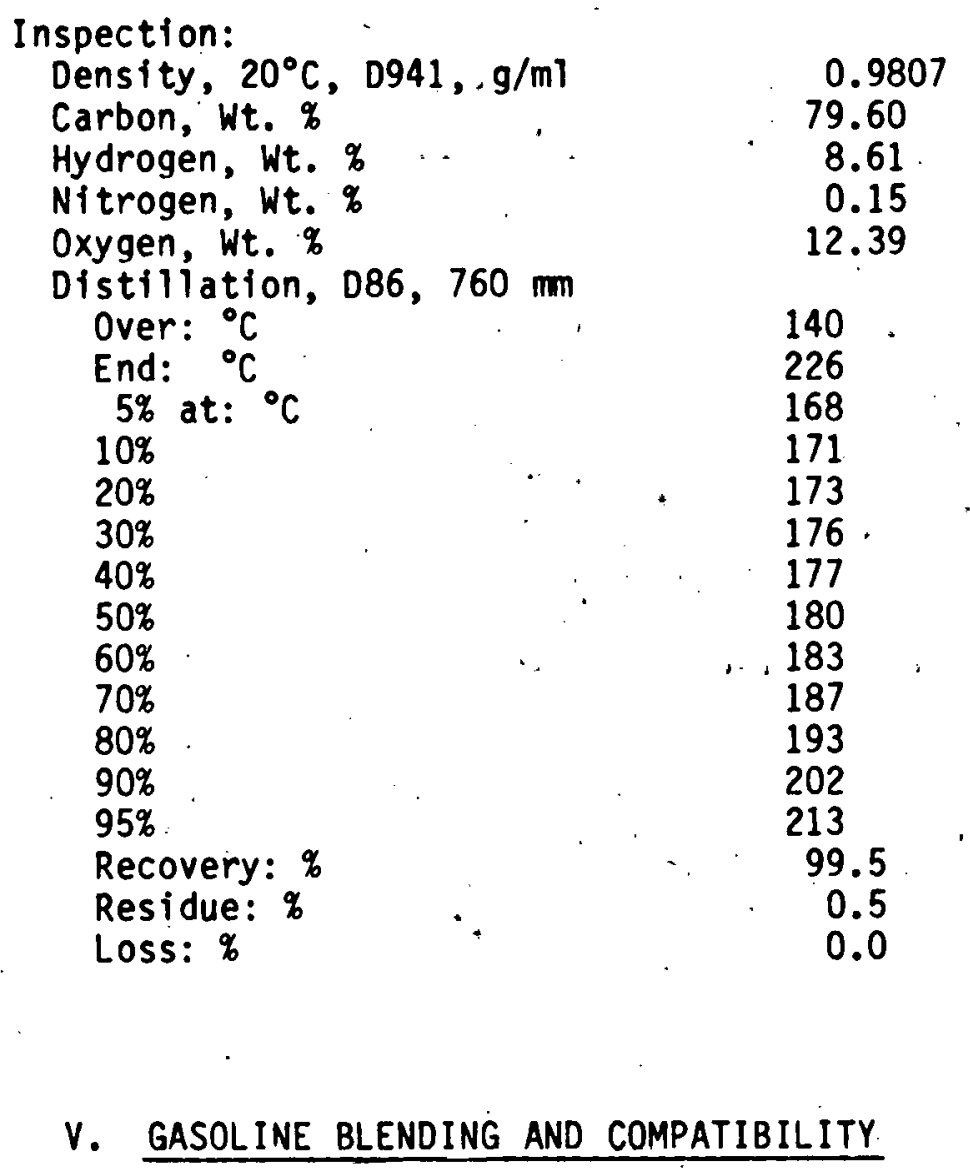

The MAE product was blended at 5 volume $\%$ with a commercial unleaded gasoline. Typical inspections of the base gasoline and the blend are given in Table 3. Apparently, some of the light ends were lost from the base gasoline when it was blended with MAE in large lots. This is indicated by the loss of vapor pressure and higher initial distillation point for the blend compared to the base gasoline in Table 3. An earlier inspection of a 5\% MAE/gasoline blend was done on a small sample that had been hand-blended in glassware (Table 4). In this case, the base gasoline is a commercial, unleaded gasoline very similar to that described in Table 3. The loss of vapor pressure for the blend in Table 4 is much less than for the blend in Table 3, and no loss in initial distillation point is shown for the blend in Table 4. 
Table 3

Inspection of Base Gasoline $A$ and $a$ Blend

of Base Gasoline $A$ and 5 Vol. \% MAE

\begin{tabular}{|c|c|c|}
\hline Inspection: & $\begin{array}{c}\text { Base A: } \\
\text { (Commercial } \\
\text { Unleaded } \\
\text { Gasoline) } \\
\end{array}$ & $\begin{array}{l}\text { Base A+ } \\
5 \text { Vol. \% } \\
\text { MAE }\end{array}$ \\
\hline 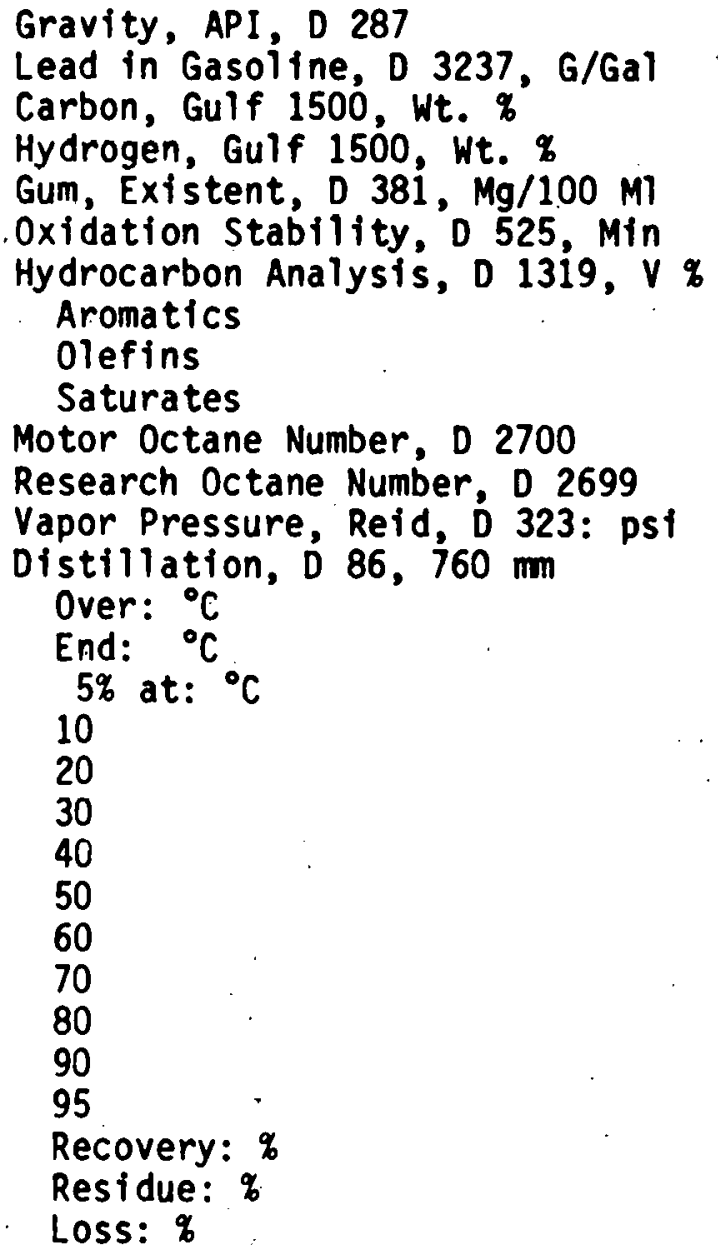 & $\begin{array}{c}58.7 \\
<0.005 \\
86.82 \\
13.18 \\
2 \\
>1440 \\
\\
26.5 \\
13.0 \\
60.5 \\
84.1^{\mathrm{a}} \\
93.2^{\mathrm{a}} \\
11.0 \\
28 \\
212 \\
39 \\
44 \\
58 \\
74 \\
89 \\
104 \\
118 \\
131 \\
147 \\
170 \\
192 \\
97.5 \\
1.4 \\
1.1\end{array}$ & $\begin{array}{r}31 \\
216 \\
41 \\
49 \\
64 \\
81 \\
97 \\
111 \\
126 \\
140 \\
156 \\
172 \\
197 \\
98.0 \\
1.2 \\
0.8\end{array}$ \\
\hline
\end{tabular}

a) Average of two ratings. 
Table 4

Inspection of Base Gasoline $B$ and $a$ Blend of Base Gasoline $B$ and 5 Vol. \& MAE

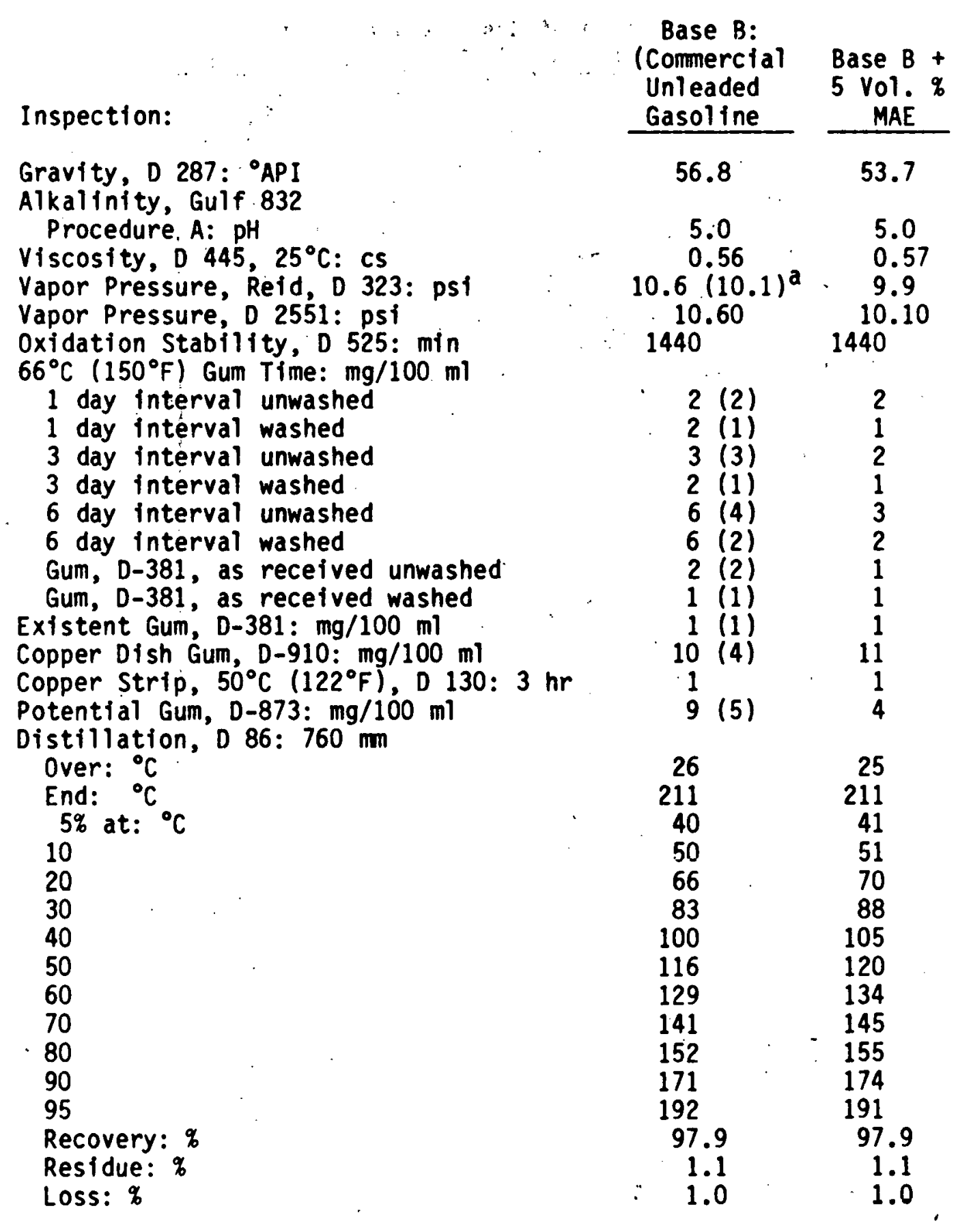

a) Numbers in parentheses are duplicate runs. 
Looking at Tables 3 and 4 together, we see that MAE is compatible with gasoline. It does not affect significantly the gasoline's specific gravity, distillation curve, alkalinity, viscosity, Reid vapor pressure, oxidation stability, existent gum value, copper dish gum value, copper strip test, or potential gum value. In addition, MAE does not separate from gasoline at low temperatures or because of water contamination.

\section{PLASTICS COMPATIBILITY}

To test the effects of $5 \%$ MAE in gasoline on plastics and elastomers commonly found in automotive gasoline distribution systems, samples of plastics and elastomers were immersed in Table 4 base gasoline and in Table 4 base gasoline containing 5 volume $\%$ MAE for five weeks at room temperature. Materials tested were Neoprene, Urethane, Adiprene, Nylon, and Nitrile rubber. Nylon was unaffected by the presence of MAE in the gasoline. The other materials swelled somewhat more in the MAE/gasoline blend than in the base gasoline but probably little more than would be caused by addition of toluene to the base gasoline. None cracked, hardened, or otherwise deteriorated (4).

\section{MICROBISTATIC PROPERTIES}

Microbial contamination of fuels can be a serious problem. To be sure that $5 \%$ MAE in gasoline does not increase the incidence of microbial contamination of the gasoline, we prepared cultures in sterile, cotton-stoppered dilution bottles. The aqueous phase consisted of Bushnell-Haas mineral salts medium inoculated with a known number of bacterial, cells cultured from contaminated water bottoms from a commercial, unleaded gasoline storage tank: The medium was aseptically dispensed into the bottles in 40, 20, and 4 $\mathrm{ml}$ amounts to give (in total culture volumes of $80 \mathrm{ml}$ ) aqueous concentrations of $50 \%, 25 \%$, and $5 \%$ respectively. 
In addition to the 5\% MAE/base gasoline (Table 4), we also tested the base gasoline itself and the base gasoline containing a commercially-available fuel-soluble. microbicide at the recommended concentration of $270 \mathrm{ppm}$. The gasoline formulations were layered over the inoculated medium in the dilution bottles to give a final volume of $80 \mathrm{ml}$. Cultures were incubated at room temperature in a fume hood. To more closely approximate gasoline storage tank conditions, the samples were not shaken. At intervals of 4,11 , and 18 days, a representative aliquot of the aqueous phase of each culture was aseptically taken, serially diluted, and plated to nutrient agar to ascertain the number of viable bacterfa. In each case the bacteria were able to grow in cultures containing. $25 \%$ and $50 \%$ water. When water in the culture medium was reduced to $5 \%$, growth : was inhibited in the culture containing 5\% MAE/gasoline blend and in the culture containing gasoline and the fuel-soluble, commercial microbicide. Bacterial growth was not inhibited in the 5\% aqueous culture by base gasoline alone. The MAE inhibited growth of the inoculum in the 5\% aqueous culture to approximately the same extent as the commercial microbicide. While microbistatic, neither was microbicidal under these test conditions. Since gasoline storage tanks normally contain less than $5 \%$ water, the presence of $5 \%$ MAE in gasoline should help control bacterial contamination (4).

\section{MAMMALIAN TOXICITY}

Samples of Table 4 base gasoline-and the Table 4 base gasoline containing 5 volume $\%$ MAE were sent to an independent testing laboratory for mammalian toxicity studies by acute oral toxicity in albino rats $(4,7)$, acute dermal toxicity in albino rabbits $(4,7)$, and acute vapor inhalation toxicity in rats $(4 ; 8)$. Both test samples were found to be relatively harmless to the rat by acute oral exposure and to be practically nontoxic to the rabbit by acute dermal exposure. In the acute vapor inhalallion study in rats, body welght gains were within normal limits and necropsy did not reveal any gross 
pathological alterations. By these tests, the mammalian toxicity of the base gasoline and the base gasoline containing $5 \%$ MAE was essentially the same.

\section{OCTANE QUALITY}

A comparison of the research octane and motor octane values for the Table 3 base gasoline and the Table 3 base gasoline containing 5\%, 10\%, and 15 volume \% MAE is given in Table 5. Based on averaging of duplicate measurements, 5\% MAE increases octane of 93 RON, 84 MON base gasoline by 0.6 RON and 0.4 MON. At 10\%, MAE increases octane by 2.2 RON and 0.9 MON. At 15\%, MAE increases octane of the base gasoline by 3.1 RON and $1.3 \mathrm{MON}$.

Table 5

Research Octane and Motor Octane Values for Base Gasoline A and Base Gasoline A Containing MAE

\begin{tabular}{|c|c|c|}
\hline Gasoline & $\begin{array}{c}\operatorname{RON}^{\mathrm{a}} \\
\left(D^{2} \quad 2699\right) \\
\end{array}$ & $\begin{array}{c}\text { MONa } \\
\left(D^{2} 2700\right) \\
\end{array}$ \\
\hline Base & 93.2 & 84.1 \\
\hline Base + 5 Vol. \& MAE & 93.8 & 84.5 \\
\hline Base + 10 Vol. \& MAE & 95.4 & 85.0 \\
\hline Base + 15 Vol. \% MAE & 96.3 & 85.4 \\
\hline
\end{tabular}

a) Average of two ratings.

Road octane quality of the base fuel (Table 3) and a blend of 5\% MAE in the base fuel was examined by testing in a selection of four different late-model cars. The experimental fuel and the base. fuel were tested for direct comparison. All ratings were made in duplicate by trained raters using the Modified Uniontown rating procedure on a chassis dynamometer. 
The cars tested were a 1979 Chevrolet Malibu 267 CIO V-8, a 49-state 1979 Ford Thunderbird 302 CID V-8, a 1979 Pontlac Catalina 301 CID V-8, and a 49-state model, 1980 Plymouth Volare equipped with a 225 CID, 6-cylinder engine. Results are shown in Table 6. For these particular cars, the four-car average gain in road octane for the MAE-containing fuel over the base fuel was 0.4 units.

Table 6

Road Octane Performance for Base Gasoline $A$ and Base Gasoline $A$ Containing 5 Vol. \% MAE.

\begin{tabular}{|c|c|c|}
\hline \multirow[b]{2}{*}{ Test Car } & \multicolumn{2}{|c|}{ Road Ratings ${ }^{a}$} \\
\hline & Base Fuel & $\begin{array}{l}\text { Base Fuel } \\
+5 \% \mathrm{MAE} \\
\end{array}$ \\
\hline 1979 Chevrolet Malibu & 89.9 & 89.9 \\
\hline 1979 Ford Thunderbird & 89.4 & 89.9 \\
\hline 1979 Pontiac Catalina & 90.0 & 91.3 \\
\hline 1980 Plymouth Volare & 87.7 & 87.8 \\
\hline 4-Car Average & 89.3 & 89.7 \\
\hline
\end{tabular}

a) Average of ratings from two different raters.

$X$. CARBURETOR CLEANLINESS

To evaluate the tendency of MAE in gasoline to form gum and varnish deposits in engine carburetors, a carburetor cleanliness test on Table 3 base gasoline and Table 3 base gasoline containing 5\% MAE was performed. The test. equipment consistod of a laturdtory engine-dynamometer set-up using a 1978 'Ford six-cylinder, 300 CID engine. The test is a modified version of the currently proposed CRC "carburetor cleanliness test. In our test cycle; the 
engine is idled for three minutes at $700 \mathrm{RPM}$, accelerated to $2000 \mathrm{RPM}$, held at 2000 RPM for seven minutes, then decelerated to idle. Increased crankcase blow-by return to the carburetor is continuous through the test cycle, whereas exhaust gas recirculation is employed only during the 2000 RPM portion of the cycle. The air/fuel ratio at idle is $11 / 1$ to $13.7 / 1$ while dynamometer loading is 45-50 ft. 1bs. at an engine speed of $2000 \mathrm{RPM}$. With controlled operating temperatures and a test duration of 22 continuous hours, selected reference gasolines cause repeatable deposit formation on a removable sleeve in the throttle body. In this case, the base gasoline gave a deposit weight of $12.4 \mathrm{mg}$ and the base gasoline containing $5 \%$ MAE gave a deposit weight of $13.0 \mathrm{mg}$. For this particular test set-up, the conclusion is that there is no difference in deposit forming characteristics between the two fuels.

\section{DRIVEABILITY PERFORMANCE}

The driveability performance of Table 3 base fuel and Table 3 base fuel containing 5\% MAE was tested on an all-weather chassis dynamometer to evaluate the experimental fuel's cold starting and warm-up characteristics. Both fuels were tested in turn in each of two test cars. Each was tested at $5^{\circ} \mathrm{F}, 25^{\circ} \mathrm{F}$, and $45^{\circ} \mathrm{F}\left(-15^{\circ},-4^{\circ},+7^{\circ} \mathrm{C}\right)$. Duplicate runs of each test were made to improve accuracy.

The chassis dynamometer used for this test program has single four foot diameter rolls, an eddy current dynamometer, an inertia weight system and an independent fan control for the cooling air. A detailed description of this precisely temperature controlled, all-weather dynamometer is given elsewhere (9). The first test car was a 1978 Ford Pinto equipped with a California 3-way exhaust catalyst and a 2.3 liter, 4-cylinder engine. The second test car was: a 1979 Pontiac LeMaris equipped with a California 3-way exhaust catalyst and a 231 cubic inch, V-6 engine. 
Testing was done under a specially developed driving procedure patterned after the CRC driveability procedure. Details of the driving procedure are given in Appendix B. Driveability demerit ratings by this procedure come out the same as in the CRC driveability procedure. The CRC demerit rating system was used, taking into account driving stall, idle stall, backfire, idle roughness, hesitation, stumbling, and surge.

Test data analysis indicates that the base fuel and the base fuel containing 5 volume $\%$ MAE are not significantly different in driveability at the $90 \%$ confidence level in the Student $t$ test. On the other hand, the same base fuel containing 10 volume $\%$ ethanol (i.e. Gasohol) was found to be significantly poorer in driveability at the $90 \%$ confidence level (Table 7 ).

Table 7

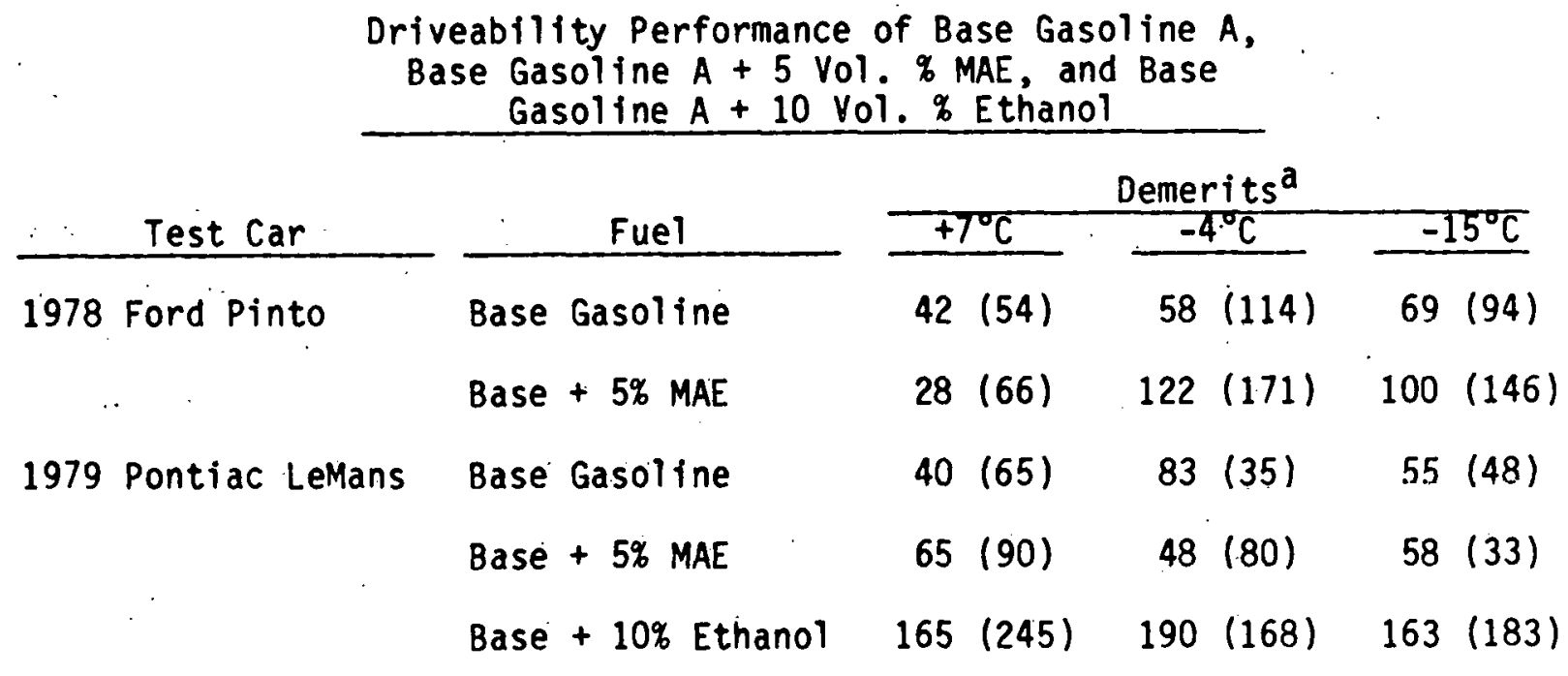

a) Numbers in parentheses are duplicate runs. 
XII. FUEL ECONOMY AND DURABILITY TESTS

Fuel economy and durability tests were made by driving each of four late-model cars (two matched pairs) for 20,000 miles on a road simulator using a typical city-suburban driving.cycle. These tests evaluated fuel economy, oil economy, intake system deposits, engine sludge and varnish deposits, engine wear, spark plug fouling, and the effects of the fuel on octane requirement increase and on exhaust gas catalyst efficiency. One car of each pair was operated on Table 3 base fuel while the other car used Table 3 base fuel containing $5 \%$ MAE. The engines were prepared with clean, measured parts and new exhaust catalysts. The engines in all four vehicles were in newly overhauled condition; each received a $500 \mathrm{mlle}$ break-in before the $20,000 \mathrm{mile}$ test was started.

The cars used in these tests were two 1979 Chevrolet Malfbus having 305 cubic inch, V-8 engines and two 1979 Ford Granadas having 302 cubic inch, $V-8$ engines. All cars were equipped with California 3-way exhaust catalysts. Following completion of the 20,000-mile runs, the engines were disassembled for inspection and measurement of intake system deposits, engine sludge and varnish deposits, engine, wear, and spark plug fouling. Exhaust catalysts were opened for inspection at conclusion of the test.

The road simulator used in the 20,000-mile test is a chassis dynamometer system for mileage accumulation. It is equipped with automatic magnetic tape control. Tight speed control is utilized, with the corresponding torque signal controlling the throttle position. This acknowledges engine degradation as it occurs throughout an extended mileage accumulation driving. schedule.

The driving cycle used on the road simulator was the "EPA Durabllity Driving Schedule for Light Duty Vehicles and Light Trucks" (10). Each test cycle is 11 raps of a 3.7 mile closed test course. The only variation from the EPA schedule is that in our test, speed on the eleventh lap was changed from $70 \mathrm{MPH}$ to $55 \mathrm{MPH}$. 


\section{A. FUEL ECONOMY}

Fuel economy measurements were made at the start, at the end, and at 5,000-mile intervals throughout the $20,000 \mathrm{mile}$ road simulator test. Measurements were made on a chassis dynamometer using the 1975 Federal Test Procedure and the EPA highway economy procedure. Detalled data are given in Appendix $C$. One cannot draw conclusions about fuel economy changes in this test because the base fuel and experimental fuel were not used in the same car and a total of only four cars was used. However, a comparison of fuel economy at start of test and end of test can be made for each car to see if MAE influences fuel economy trends over the 20,000-mile test. This comparison is shown in Table 8 where data was abstracted from Appendix $C$. Duplicate runs in Appendix $C$ were averaged for use in Table 8.

Table 8

Fuel Economy Performance (mpg) of Base Gasoline A and Base Gasoline A Containing 5 Vor. \& MAE

(Data taken from Appendix C)

1979 Chevrolets

\begin{tabular}{|c|c|c|c|c|c|c|}
\hline Test Miles & $\frac{\text { Base }_{b}}{\text { city }^{6}}$ & $\frac{\text { soline }}{\text { cityc }}$ & $\frac{(\operatorname{car} 1)}{\text { Highway }}$ & $\frac{\text { Base }}{\text { Cfty }}$ & $\frac{n e+5 q}{c 1 t y^{c}}$ & $\frac{\text { MAE (Car 2 }}{\text { HTghwayce }}$ \\
\hline $\mathrm{Ni}$ & 13.95 & 13.50 & 21.70 & 13.95 & 13.80 & 20.05 \\
\hline 20,000 & 15.25 & 14.60 & 22.10 & 15.25 & 15.25 & 20.85 \\
\hline Change & +1.30 & +1.10 & +0.40 & +1.30 & +1.45 & +0.80 \\
\hline
\end{tabular}

1979 Fords

Test Miles Base Gasoline (Car 1)

$\begin{array}{lllllll}\text { N11 } & 15.10 & 14.90 & 22.15 & 15.00 & 15.10 & 21.20\end{array}$

$20,000 \quad \underline{14.60} \quad \underline{13.90} \quad \underline{21.40} \quad \underline{14.75} \quad \underline{14.40} \quad \underline{21.05}$

$\begin{array}{lllllll}\text { Change } & -0.50 & -1.00 & -0.75 & -0.25 & -0.70 & -0.15\end{array}$

a) City portion determined by 1975 city-suburban FTP; highway portion determined by EPA highway fuel economy procedure.

D) Determined by the carbun balance method.

c) Determined gravimetrically. 
Table 8 shows that both Chevrolets gained in fuel economy during the 20,000-mile test, the one using fuel containing 5\% MAE apparently gaining most. Both Fords lost in fuel economy during the test, the Ford using fuel containing 5\% MAE losing least. This test is too small to say if these differences are real. Basically, the fuel economy trends over 20,000 miles appear the same whether MAE is present in the fuel or not.

B. SPARK PLUG FOULING

No instance of spark plug fouling occured in any car over the $20,000-$ mile test.

C. OIL CONSUMPTION

0 il consumption, measured in miles per quart over the 20,000-mile test was normal (Appendix D). Both the Ford and the Chevrolet using base fuel containing 5\% MAE consumed less oil than their counterparts using base fuel, but the difference is not significant.

\section{OCTANE REQUIREMENTS}

The octane requirements of all four vehicles were measured on a chassis dynamometer at the start, the end, and at 5000-mile intervals throughout the 20,000-mile test (Appendix E). Analysis indicates that the presence of MAE in the fuel has no significant effect on octane requirement.

\section{E. ENGINE WEAR}

Engine wear overall was very low in all four vehicles. Presence of MAE in the fuel did not cause a significant difference in engine wear (Appen$\operatorname{dix} F$ ). 


\section{F. ENGINE DEPOSITS}

All four vehicles had fairly clean engines after the 20,000-mile test, showing only light sludge and varnish. Generally, the presence of MAE in the fuel caused no significant difference in engine deposits except that in the ford using fuel containing 5\% MAE, varnish appeared somewhat heavier on the rocker arm covers, pistons, and valve lifters (Appendix G).

\section{G. EXHAUST EMISSIONS}

Exhaust emissions of $\mathrm{HC}, \mathrm{CO}$, and $\mathrm{NO}_{x}$ were made at the start, at the end, and at 5000-mile intervals throughout the 20,000-mile test. Measurements were made on a chassis dynamometer (Appendix H). Emissions for the two Chevrolets at the start and at the conclusion of the test are given in Table 9. The data in Table 9 are abstracted from Appendix $H$. Duplicate runs in Appendix $H$ are averaged for use in Table 9.

Table 9

Exhaust Emissions (grams/mile) From Two 1979

Chevrolet Malibu Test Cars Using 1975 FTP (Data taken from Appendix $H$ )

\begin{tabular}{|c|c|c|c|c|c|c|}
\hline \multirow[b]{2}{*}{ Test Miles } & \multirow{2}{*}{$\begin{array}{l}\text { Base } \\
\mathrm{HC} \\
\end{array}$} & \multirow{2}{*}{$\frac{\text { iasoline }}{\mathrm{CO}}$} & \multirow{2}{*}{$\frac{(\operatorname{Car} 1)}{\text { Nox }}$} & \multicolumn{3}{|c|}{$\begin{array}{l}\text { Base Gasoline } \\
+\quad 5 \% \operatorname{MAE~(Car~2)~}\end{array}$} \\
\hline & & & & $\overline{H C}$ & $\mathrm{CO}$ & NOX \\
\hline $\mathrm{Nil}$. & 0.40 & 6.12 & 0.79 & $0: 42$ & 5.58 & 0.62 \\
\hline 20,000 & 0.69 & 8.05 & 0.77 & 0.45 & 5.55 & 0.68 \\
\hline Change & +0.29 & +1.93 & -0.02 & +0.03 & -0.03 & +0.06 \\
\hline
\end{tabular}

We see in Table 9 that emissions at the end of the test are somewhat lower from the chevrolet using base fuel containing $5 \%$ MAE than from the Cherrolet using base fuel alone. But. since both fuels were not tested in the same car, no conclusion can be drawn, except to say that MAE does not appear to increase exhaust emissions. 
Exhaust emissions from the Ford using the 5\% MAE/base fuel blend are all slightly lower at start of test compared to emissions from the ford using base fuel alone. However, emissions from the Ford using the MAE-containing fuel increased significantly during the 20,000-mile test (Appendix H). Examination of the monolith catalyst after test conclusion on the Ford using MAE-containing fuel showed it to have a. deformed area of about two square inches in the center of the catalyst (Appendix I). Catalyst deformation is probably unrelated to the particular fuel used. Being a monolithic catalyst, this channel may have allowed the increase in exhaust emissions. Exhaust emissions results on this car are probably invalid. 
XIII. CONCLUSIONS

The research discussed in this paper indicates that the mixture of methyl aryl ethers (MAE) derived from phenols present in raw coal liquids is an excellent non-metallic gasoline blending agent and octane improver. Use of MAE in gasoline should help alleviate the curent need for increased petroleum refining severity to make metal-free, high octane gasoline. Additionally, removing phenols from raw coal liquids for conversion to MAE may reduce some coal liquid refining problems and should allow a significant reduction in hydrogen consumption needed to upgrade coal liquids.

APPENDIX A

PREPARATION OF METHYL ARYL ETHERS (MAE) - A composite of raw coal liquid from 51 runs on a variety of Eastern bituminous coals fed to Gulf Research \& Development Company's one ton/day SRC II process demonstration unit was used as the source of phenols. The fraction of the composite used was that boiling in the range $55^{\circ} \mathrm{C}\left(131^{\circ} \mathrm{F}\right)$ to $260^{\circ} \mathrm{C}\left(500^{\circ} \mathrm{F}\right)$. This composite fraction (1019 gallons, 7574 lbs) was shipped to Chemsampco (now known as Albany. International, Chemical Division) in Columbus, Ohio, where phenols were extracted from the coal liquid and converted to MAE.

Two runs of about 510 gallons of coal liquid were extracted with 175 gallons of $20 \%$ aqueous sodium hydroxide per run. The extractions were run at $35^{\circ} \mathrm{C}$ with stirring for 6 hours. The lower aqueous layer (pH 10) containing the sodium salts of the phenols was separated from the top neutral layer. The lower, basic aqueous layers from the two extractions were combined and washed by stirring with 200 gallons of ether for 6 hours at $20^{\circ} \mathrm{C}$ to remove non-phenolic organic compounds. The top ether layer was separated and discarded. The lower aqueous layer was checked for non-phenolic, neutral hydrocarbons by a small scale extraction of an aliquot with ether and found to contain insignificant amounts. The basic, aqueous layer was then stripped of residual ether to a pot temperature of $55^{\circ} \mathrm{C}$ with stirring. 
The basic, aqueous layer (still containing the sodium salts of the phenols) was then acidified with aqueous $20 \%$ hydrochloric acid to a pH of 2 with stirring and cooling to maintain a temperature of $20^{\circ} \mathrm{C}$ in the reactor. This acidification converted the sodium salts of the phenols to free phenols. Sodium chloride (500 lbs) was added to decrease the solubility of the free phenols in the water. After 2 hours to allow complete phase separation into a lower aqueous phase and an upper phenols phase, the lower aqueous layer was checked by gas chromatography for phenols; none were found. The lower aqueous layer was then discarded. The remaining phenolic layer was washed twice with a mixture of 50 gallons of water, 100 lbs of sodium carbonate, and 50 lbs. of sodium chloride. The lower wash water layer was checked by gas chromatography for phenols (none found) and was discarded.

At this point there remained 2180 lbs (28.8 wt. \%) of phenolics. of the 2180 lbs. of phenolics, 1850 lbs. was used for conversion to MAE. To $1850^{\circ}$ ibs. phenolics was added 2 drums of $50 \%$ aqueous sodium hydroxide and 1200 lbs. water (to give a 25 wt. \% aqueous sodium hydroxide solution). The reaction mixture was stirred with cooling $\left(18^{\circ} \mathrm{C}\right)$ for 8 hours. Dimethyl sulfate $(2200$ 1bs.) was then added with stirring over 10 hours, keeping the temperature of the reaction mixture below $34^{\circ} \mathrm{C}$. The reaction mixture was then stirred at $20^{\circ} \mathrm{C}$ for 36 hours. Aqueous $50 \%$ sodium hydroxide (20 gallons) was then added to destroy excess dimethyl sulfate and remove any unetherified phenol from the crude MAE product. The mixture was stirred one hour, allowed to separate into layers, and the lower aqueous, basic phase was discarded. The remaining MAE product layer was washed with a mixture of 50 gallons water, 25 gallons of $50 \%$ aqueous sodium hydroxide, and 25 lbs. of sodium chloride. The lower, aqueous wash layer was discarded to give 1801 lbs. of MAE. The crude MAE was distilled to give 65 ibs. of non-MAE-containing first cut (boiling $44^{\circ}-69^{\circ} \mathrm{C}$ at $58-100 \mathrm{~mm} \mathrm{Hg}$ ), 1440 lbs. (176 gallons) of MAE (boiling $73-117^{\circ} \mathrm{C}$ at $30-50 \mathrm{~mm} \mathrm{Hg}$, and 99 lbs. of a heavy, dark residue. Material loss was due to light material being pulled through traps and pumps. Also some material caked to the walls of the distillation unit. 
APPENDIX B

DRIVEABILITY PROCEDURE - The driveability test is performed by operating the car at specific throttle openings over the driving cycle which is pre-recorded on a visual drivers aid. This cycle includes the following: (1) set choke and start engine, (2) fast idle in neutral for 15 seconds, (3) transmission in drive for 5 seconds, (4) part throttle acceleration 0-25 $\mathrm{mph}$, (5) $25 \mathrm{mph}$ cruise for 0.1 miles, (6) detent acceleration 25 to $40 \mathrm{mph}$, (7) $40 \mathrm{mph}$ cruise for 0.2 miles then decelerate to $20 \mathrm{mph}$, (8) part throttle acceleration from 20 to $40 \mathrm{mph}$, (9) brake to a stop and idle for 30 seconds.

The above cycle is repeated 3 times for a total of 2.2 miles. Then - the following cycle is performed 4 times for a total test of 5.1 miles: (1) part throttle acceleration 0-45 $\mathrm{mph}$, (2) cruise for 0.2 miles then decelerate to $25 \mathrm{mph},(3)$ detent acceleration to $40 \mathrm{mph}$ and cruise for 0.1 miles, (4) decelerate to $20 \mathrm{mph}$ and cruise for $0.1 \mathrm{miles,} \mathrm{(5)} \mathrm{part} \mathrm{throttle} \mathrm{accelera-}$ tion to $40 \mathrm{mph}$, (6) brake to a stop and idle for 30 seconds.

\section{APPENDIX C}

FUEL ECONOMY TESTS, MPH, 1975 CITY-SUBURBAN

FTP AND EPA HIGHWAY FUEL ECONOMY PROCEDURES

1979 Chevrolets

\begin{tabular}{|c|c|c|c|c|c|c|}
\hline \multirow[b]{2}{*}{$\begin{array}{l}\text { Test } \\
\text { Miles }\end{array}$} & \multicolumn{3}{|c|}{ Báse Fuel } & \multicolumn{3}{|c|}{ Base + $5 \%$ MAE } \\
\hline & $\begin{array}{c}\text { City } \\
\text { Carb. Bal. }\end{array}$ & $\begin{array}{l}\text { City } \\
\text { Gravim. }\end{array}$ & $\begin{array}{l}\text { Highway } \\
\text { Gravim. }\end{array}$ & $\begin{array}{c}\text { City } \\
\text { Carb. Bal } \\
\end{array}$ & $\begin{array}{l}\text { City } \\
\text { Gravim. }\end{array}$ & $\begin{array}{l}\text { Highway } \\
\text { Gravim. }\end{array}$ \\
\hline $\begin{array}{c}0 \\
0 \\
5,000 \\
10,000 \\
15,000 \\
20,000 \\
20,000\end{array}$ & $\begin{array}{l}13.7 \\
14.2 \\
15.3 \\
14.5 \\
15.6 \\
15.3 \\
15.2\end{array}$ & $\begin{array}{c}13.5 \\
- \\
15.4 \\
14.0 \\
15.0 \\
14.7 \\
14.5\end{array}$ & $\begin{array}{c}21.6 \\
21.8 \\
- \\
- \\
- \\
22.3 \\
21.9\end{array}$ & $\begin{array}{l}14.1 \\
13.8 \\
14.8 \\
14.9 \\
14.6 \\
15.2 \\
15.3\end{array}$ & $\begin{array}{l}13.8 \\
- \\
14.3 \\
14.6 \\
14.3 \\
15.2 \\
15.3\end{array}$ & $\begin{array}{c}19.9 \\
20.2 \\
- \\
- \\
- \\
20.7 \\
21.0\end{array}$ \\
\hline
\end{tabular}


1979 Fords

\begin{tabular}{|c|c|c|c|c|c|c|}
\hline \multirow[b]{2}{*}{$\begin{array}{r}\text { Test } \\
\text { Miles } \\
\end{array}$} & \multicolumn{3}{|c|}{ Base Fuel } & \multicolumn{3}{|c|}{ Base $+5 \%$ MAE } \\
\hline & $\begin{array}{c}\text { City } \\
\text { Carb. Bal. } \\
\end{array}$ & $\begin{array}{c}\text { Crty } \\
\text { Gravim. }\end{array}$ & $\begin{array}{l}\text { Highway } \\
\text { Gravim. }\end{array}$ & $\begin{array}{c}\text { City } \\
\text { Carb. Bal. }\end{array}$ & $\begin{array}{l}\text { Crty } \\
\text { Gravim. }\end{array}$ & $\begin{array}{l}\text { Highway } \\
\text { Gravim. }\end{array}$ \\
\hline $\begin{array}{c}0 \\
0 \\
5,000 \\
10,000 \\
15,000 \\
20,000 \\
20,000\end{array}$ & $\begin{array}{l}14.9 \\
15.3 \\
16.1 \\
16.2 \\
16.1 \\
13.8 \\
15.4\end{array}$ & $\begin{array}{c}14.9 \\
- \\
15.1 \\
15.4 \\
15.0 \\
13.0 \\
14.8\end{array}$ & $\begin{array}{c}22.2 \\
22.1 \\
- \\
- \\
- \\
21.1 \\
21.7\end{array}$ & $\begin{array}{l}15.1 \\
14.9 \\
15.8 \\
15.3 \\
14.8 \\
14.6 \\
14.9\end{array}$ & $\begin{array}{c}15.1 \\
- \\
15.3 \\
14.9 \\
14.2 \\
14.4 \\
14.4\end{array}$ & $\begin{array}{c}21.0 \\
21.4 \\
- \\
- \\
20.8 \\
21.3\end{array}$ \\
\hline
\end{tabular}

\section{APPENDIX D}

OIL CONSUMPTION DURING 20,000-MILE ROAD SIMULATOR TEST

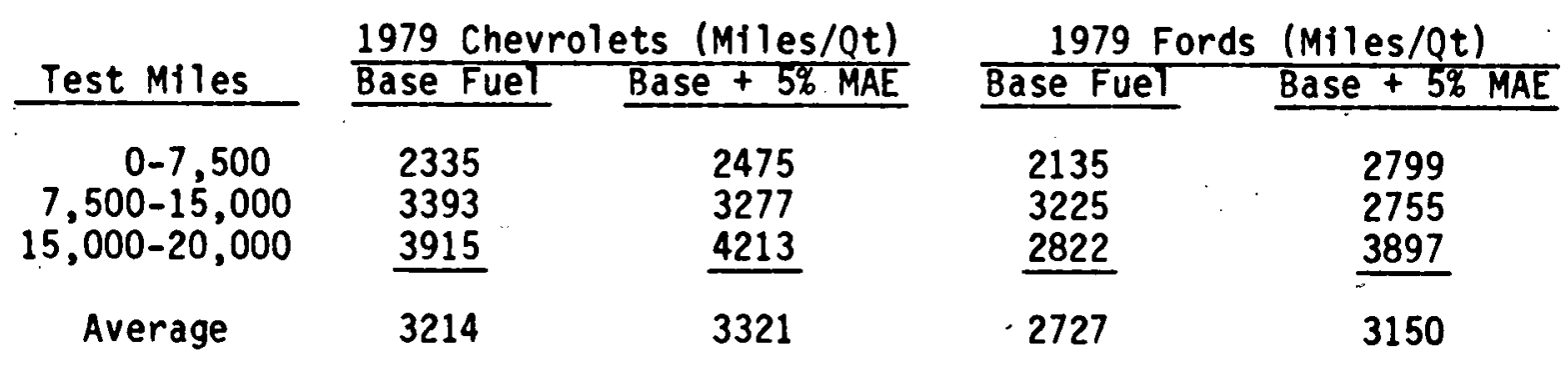


OCTANE REQUIREMENTS

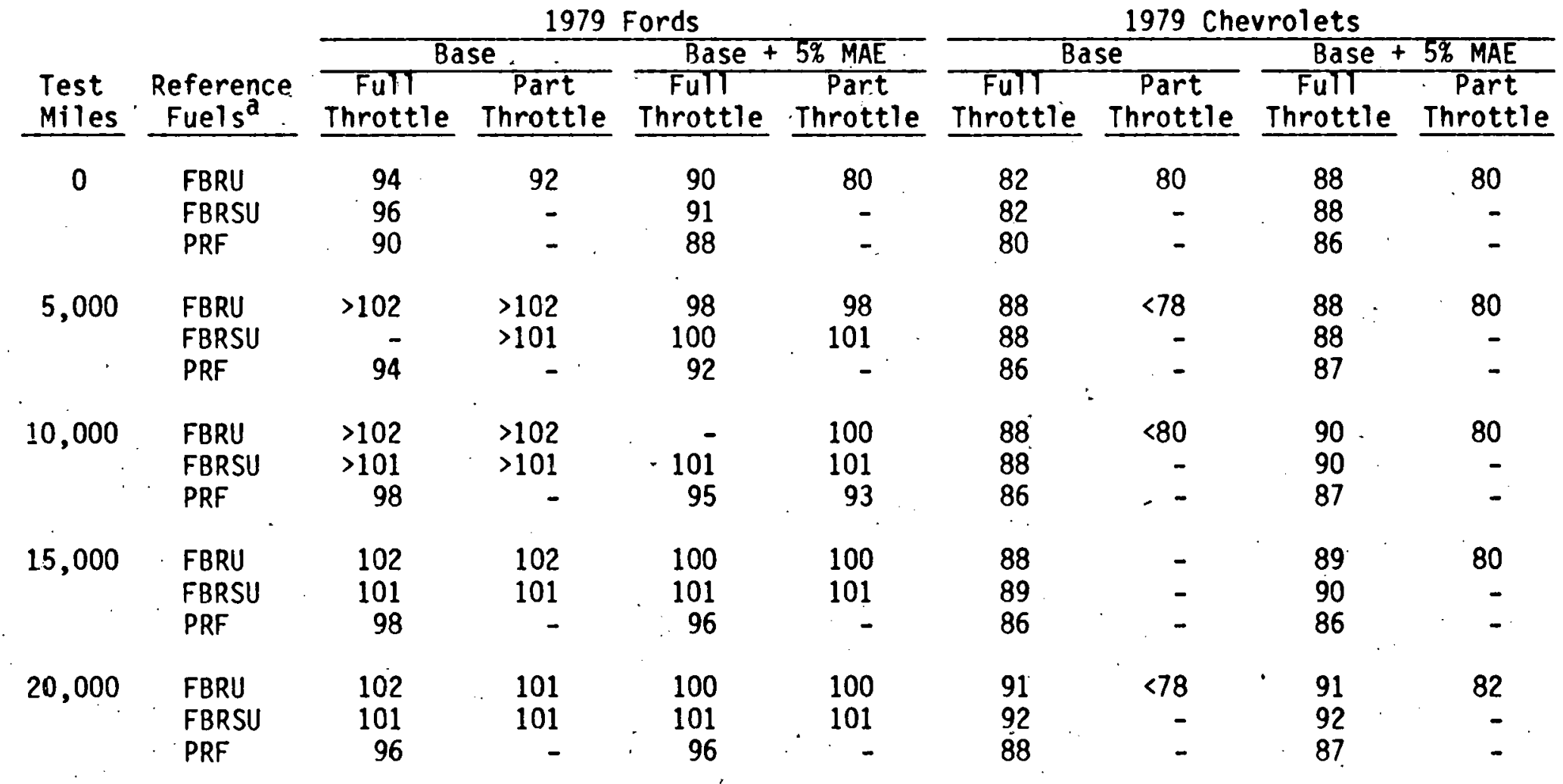

a) FBRU are 1979 CRC Full Boiling Range Unleaded fuels. FBRSU are 1979 CRC Full Boiling Range Sensitive Unleaded fuels. PRF are Primary Referen:e Fuels. 


\section{ENGINE WEAR MEASUREMENTS}

PISTON RINGS:

1979 Chevrolets
Base Fuel Base + 5\% MAE Base Fuel
Buase, + 5\% MAE

Top Compression:

Max, gms

Second Compression:

Avg, gms

Max, gms

0.022

0.030

0.037

0.071

0.068

0.081

0.079

0.005

0.015

0.044

0.114

0.016

0.018

0.053

0.045

CONNECTING ROD BEARINGS

Avg, gms

Max, gms

0.055

0.074

0.055

0.074

0.030

0.049

0.052

CAM AND LIFTERS, wear, in.

\author{
Avg lobe \\ Max lobe \\ Avg lifter \\ Max lifter \\ Avg combined \\ Max combined \\ Lifter spalling, scuffing \\ Lobe spalling, scuffing
}

VALVE CLEAR WEAR:

Valve tips

Rocker arm pads

$\begin{array}{cccc}0.0002 & 0.0001 & 0.0011 & 0.0002 \\ 0.0004 & 0.0002 & 0.0022 & 0.0006 \\ 0.0002 & 0.0002 & 0.0004 & 0.0006 \\ 0.0004 & 0.0005 & 0.0008 & 0.0013 \\ 0.0004 & 0.0003 & 0.0015 & 0.0009 \\ 0.0005 & 0.0007 & 0.0026 & 0.0018 \\ \text { nil } & \text { nil } & \text { trace to light } & \text { trace to light } \\ \text { nil } & \text { nil } & \text { trace to light } & \text { trace to light }\end{array}$

light

light very light trace to light very light

trace to light light to moderate

trace to light 


\section{APPENDIX G}

\section{ENGINE DEPOSITS}

(Numerical ratings from 0 to 10, 10 being clean according to CRC Rating Scale)

SLUDGE:

Timing gear cover

Intake mantfold

Left rocker cover

Right rocker cover

$0 i 1$ pan

0 il screen.

VARNISH:

Timing gear cover

Intake manifold

Left rocker cover

Right rocker cover

011 pan

Pistons, average

Valve lifters, average

\section{OTHER:}

Intake valve stems

Intake valve fillets

Intake valve dep. wt, gms

Exhaust valve dep. wt, gms

Ring sticking

Valve iffter sticking

\begin{tabular}{r}
197 \\
\hline Base Fuel \\
\hline 9.5 \\
9.3 \\
8.7 \\
9.0 \\
9.0 \\
10.0 \\
\end{tabular}

10.0

7.8

6.2

8.3

9.2

6.6

8.9

4.9

7.7

2.4

0.24

nil

nil

\section{Fords}

Base Fuel Base + 5\% MAE

9.4

9.1

9.0

9.5

8.7

9.0

8.8

10.0

10.0

8.5

6.5

8.0

9.5

6.2

9.1

5.3

6.8

2.4

0.23

nil

nil
8.1

8.9

8.8

9.9

9.2

8.4

9.2

8.8

9.9

9.5

6.8

7.7

9.0

9.5

6.4

6.6

9.0

7.0

4.0

8.0

9.0

5.8

5.9

5.9

5.9

3.4

0.01

nil

nil
4.7

5.3

5.0

0.02

three sluggish nil 


\section{APPENDIX H}

EXHAUST EMISSIONS, GMS/MILE

1975 FEDERAL TEST PROCEDURE

1979 Chevrolets

\begin{tabular}{|c|c|c|c|c|c|c|}
\hline \multirow{2}{*}{$\begin{array}{l}\text { Test } \\
\text { Miles }\end{array}$} & \multicolumn{3}{|c|}{ Base Fuel } & \multicolumn{3}{|c|}{ Base + 5\% MAE } \\
\hline & $\overline{\mathrm{HC}}$ & $\mathrm{CO}$ & NOX & $\mathrm{HC}$ & $\mathrm{CO}$ & NOX \\
\hline $\begin{array}{c}0 \\
0 \\
5,000 \\
10,000 \\
15,000 \\
20,000 \\
20,000\end{array}$ & $\begin{array}{l}0.32 \\
0.48 \\
0.52 \\
0.69 \\
0.75 \\
0.68 \\
0.69\end{array}$ & $\begin{array}{l}5.73 \\
6.51 \\
6.19 \\
7.86 \\
8.20 \\
7.39 \\
8.71\end{array}$ & $\begin{array}{l}0.75 \\
0.83 \\
0.74 \\
0.80 \\
0.83 \\
0.80 \\
0.74\end{array}$ & $\begin{array}{l}0.41 \\
0.42 \\
0.50 \\
0.66 \\
0.66 \\
0.44 \\
0.45\end{array}$ & $\begin{array}{r}5.68 \\
5.47 \\
7.65 \\
7.10 \\
12.39 \\
5.47 \\
5.63\end{array}$ & $\begin{array}{l}0.61 \\
0.62 \\
0.72 \\
0.76 \\
0.90 \\
0.67 \\
0.68\end{array}$ \\
\hline & & & & & & \\
\hline
\end{tabular}

\begin{tabular}{|c|c|c|c|c|c|c|}
\hline \multirow{2}{*}{$\begin{array}{l}\text { Test } \\
\text { Miles }\end{array}$} & \multicolumn{3}{|c|}{ Base Fuel } & \multicolumn{3}{|c|}{ Base $+5 \%$ MAE } \\
\hline & $\overline{\mathrm{HC}}$ & $\mathrm{CO}$ & NOX & $\mathrm{HC}$ & co & NOx \\
\hline $\begin{array}{c}0 \\
0 \\
5,000 \\
10,000 \\
15,000 \\
20,000 \\
20,000\end{array}$ & $\begin{array}{l}0.47 \\
0.46 \\
0.67 \\
0.86 \\
0.98 \\
1.25 \\
1.41\end{array}$ & $\begin{array}{r}2.31 \\
3.01 \\
4.15 \\
4.45 \\
4.31 \\
13.15 \\
5.96\end{array}$ & $\begin{array}{l}0.93 \\
0.86 \\
1.05 \\
1.05 \\
0.95 \\
1.10 \\
0.80\end{array}$ & $\begin{array}{l}0.28 \\
0.31 \\
1.18 \\
1.57 \\
1.95 \\
3.31 \\
4.35\end{array}$ & $\begin{array}{l}1.12 \\
1.23 \\
2.94 \\
5.11 \\
7.77 \\
6.48 \\
5.93\end{array}$ & $\begin{array}{l}0.85 \\
0.88 \\
1.38 \\
1.29 \\
1.35 \\
2.65 \\
2.47\end{array}$ \\
\hline
\end{tabular}




\section{APPENDIX I}

EXHAUST GAS CATALYST INSPECTION

AFTER 20,000 MILES OF OPERATION

\begin{tabular}{|c|c|c|c|c|}
\hline Car: & Chevrolet & Chevrolet & Ford & Ford \\
\hline Fuel: & Base & Base + 5\% MAE & Base & Base + 5\% MAE \\
\hline Type Catalyst: & Pellet & Pellet' & Monolith & Monolith \\
\hline Plugging: & None & None & None & None \\
\hline Condition: & $\begin{array}{l}\text { Severe damage } \\
\text { to lower shelf; } \\
\text { melted areas, } \\
\text { pellets spllied } \\
\text { and several } \\
\text { fused masses } \\
\text { about } 1 / 2 \text { in } \\
\times 1-1 / 2 \text { in }\end{array}$ & Good & Good & $\begin{array}{l}\text { Deformed area } \\
\text { about } 2 \text { sq. in. } \\
\text { in center of } \\
\text { catalyst }\end{array}$ \\
\hline
\end{tabular}




\section{REFERENCES}

1. W.K. Lan, Gulf Résearch.\& Development Company internal report, Reference No. 633TG986, September 30, 1976.

2. Battelle Energy Program Report, "Llquefaction and Chemical Refining of Coal", Battelle-Columbus, July, 1974.

3. S.A. Holmes, et al, "Characterization of Coal Liquids Derived From the H-Coal Process", ERDA Technical Information Center, No. BERC/R176/10, November, 197.6.

4. G.M. Singerman, "Coal-Derived Motor Fuels, Gulf Research \& Development Company internal report No. 531RH068, February 3, 1977.

5. T. Johnson, et al, "Distillation Tower Corrosion--Synergistic Effect of Chlorine and Phenolic Compounds in Coal Liquids", Report No. IMMR48-PD23-80, Institute for Mining and Mineral Research, University of Kentucky, Lexington, KY, March, 1980.

6. A. Schneider, et al (Suntech, Inc.), "Research and Development of an Advanced Process for the Conversion of Coal to Synthetic Gasoline and Other Distillate Fuels", Quarterly Technical Progress Report No. 9, Prepared for the U.S. Energy Research and Development Administration under Contract No. EF-76-C-01-2306, October, 1979.

7. Industrial Bio-Test Laboratories Report No. IBT-8530-09322 to E.E. Sandmeyer, Gulf $0 i 1$ Corporation Medical Department, October 4, 1976.

8. Industrial Bio-Test Laboratories Report No. IBT-8562-09323 to E.E. Sandmeyer, Gulf $0 i 1$ Corporation Medical Department, August 24, 1976. 


\section{REFERENCES (cont'd)}

9. E.W. Jacobson, et a1, "Gulf's New Automotive Laboratory--A Design for Versatility", Society of Automotive Engineers, 72A, August 14, 1958.

10. Appendix-B, Federal Register, Volume 3, No. 108, June 4, 1968. 
United States

Department of Energy

Washington, D.C. 2068
Postage and Fres Paid

U.S. Depertment of Enerey DOE-360

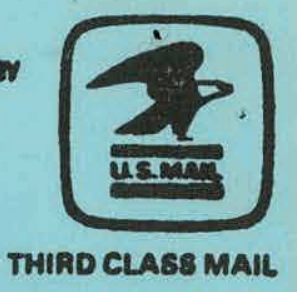

THIFD CLASB MAIL

Offleial Bualnese

Penalty for Private Use, $\$ 300$ 